\author{
Review Article \\ www.ijrap.net
}

\title{
STUDY OF ATYAMBUPANA AS A PRAMEHAHETU
}

Nilesh Dilipkumar Sharma *

P.G. Scholar, Department of Ayurveda Samhita and Siddhant, PDEA's College Of Ayurveda And Research Centre, Nigdi, Pune, Maharashtra, India

Received on: 18/03/16 Revised on: 13/04/16 Accepted on: 23/04/16

\author{
*Corresponding author \\ E-mail: ndsharma@gmail.com
}

DOI: 10.7897/2277-4343.073103

\begin{abstract}
Prameha (diabetes) is a metabolic disorder with ever increasing prevalence on global level. It is considered to be one of the important causes of global deaths due to non-communicable diseases (NCDs). No complete cure for Prameha (diabetes) is available in today's era. Prevention is the only key for its control. Avoiding the etiological factors plays the most important role for disease prevention. Ayurveda has considered Atidravapana (excess liquid intake) as an etiological factor for Prameha (diabetes). Out of the day to day consumed liquids, only Atyambupana (excess water intake) is taken into consideration during this study. This study aims to understand the probable pathophysiology of Prameha (diabetes) due to Atyambupana with the help of Ayurveda Samhitas and modern medical science. To prove its practicalities, this study gives an opportunity for further research with the help of survey studies.
\end{abstract}

Key words: Prameha (diabetes), Atyambupana (excess water intake), Prevention.

\section{INTRODUCTION}

For the interpretation of various concepts, some basic principles have been accepted in Ayurveda. The cause - effect relationship in all respects is also one of them. So, in Ayurvedic Samhitas, description of Vyadhihetu (aetiological factors for any disease) with respect to materialistic, mental or physical activity can be seen. Prameha (diabetes) is a disease; originating from metabolic disturbances in the body with increasing prevalence globally. In the list of Pramehahetu, there is one Hetu (aetiological factor) called 'Atidravpana' ' meaning excess liquid intake. Atidravpana includes variety of liquid intakes like water, milk, tea, coffee, buttermilk, liquor, carbonated/aerated beverages, juices, soups etc. Out of all these, drinking of water is inevitable part of our life. Now-a-days, Atyambupana (excess water intake) is advocated by many health professionals through different social media \& personal counselling. People follow these advices \& practice Atyambupana in different ways. For example, excess water intake at empty stomach in the morning, before/during/immediately after the meals etc. This can give rise to many pathological effects in the body. But, the present study has been restricted to Atyambupana (excess water intake) only.

World health statistics published by WHO states that the percentage of global deaths due to non-communicable disease [NCD] like diabetes, cardiovascular diseases, cancers, chronic respiratory diseases is $57.9 \%$ in males and $61.4 \%$ in females. Diabetes is directly responsible for $3.5 \%$ of total deaths due to NCDs. Even it has been predicted that the number of patients of diabetes will be doubled by the year 2030. The causes of such deaths are unhealthy food habits, physical inactivity, addiction and stress. Prevention is the only key to control this ${ }^{2}$. The aim of Ayurveda is also Swasthyarakshan (prevention of diseases). ${ }^{3}$

\section{DISCUSSION}

Body is composed of Rasa Dhatu and Rasa Dhatu is made up of water $^{4}$. Modern medical science also states that water is the most abundant constituent in the body, accounting for $50 \%$ of body weight in women and $60 \%$ in men $^{5}$. For the sustenance of life, water is a basic requirement, that doesn't mean more water you consume the better health you will have. Hence optimum water intake according to the need of body should be taken. This has been already mentioned by Ayurvedic Samhitas that regular excess water intake can lead to various pathological conditions like Chhardi, ${ }^{6}$ Pratishyay, ${ }^{7}$ Udar $^{8}$, Prameha 9 , Sthaulya ${ }^{10}$, Agnisada $^{11}$, Grahani ${ }^{12}$, Atisar ${ }^{13}$, Klaibya $^{14}$, Shwas $^{15}$, Shirorog $^{16}$ etc. Ayurveda has clearly mentioned the relationship of excess water intake as an etiological factor of Prameha long before. Prameha can be correlated with diabetes.

If water is taken in excess quantity, it leads to increase in Kapha Dosha and Jatharaagnimandya, which ultimately gives rise to Dhatvagnimandya ${ }^{17}$. This excess water intake causes Anivishtattva / Shaithilya / Abaddhatva (flaccidity) in all Dhatu and Mala of body except Asthi. It then leads to abnormal increase in Dhatu ${ }^{18}$. This Agnivikruti leads to disturbance in the production, nourishment and functioning of Dhatu; which creates metabolic disturbances in the body. An imbalance is created in normal catabolism and anabolism of body cells leading to excess formation of Kleda. This excess Kleda is excreted out of the body by Mutra ${ }^{19}$, giving rise to Prabhutamutrata (increased frequency and quantity of urine). Prabhutamutarata is an important symptom of Prameha (diabetes). ${ }^{20}$ Apana Vayu is responsible for the expulsion of Shukra, Aartav, Purish, Mutra \& Garbha out of the body at proper time. ${ }^{21}$ Vyana Vayu is responsible for the transportation of Rasa from Hruday (heart) to the each \& every minute cell of the body, by which body cells get nourishment. ${ }^{22}$ If Atyambupana is done habitually, Vyana Vayu has to circulate this excess water all over the body through Rasa. ${ }^{23}$ As explained above, the excess amount of Kleda is taken to Basti (urinary bladder); giving rise to increase in the quantity \& frequency of micturition. In this way, vitiation of Vyana \& Apana Vayu due to Atyambupana gives rise to Prameha (diabetes). ${ }^{24}$ 
Everything in this world is composed of Pancha Mahabhoota. ${ }^{25}$ Besides its Panchabhautikatva; water has predominance of Jala Mahabhoota. Hence, out of the twenty Gurvadi (Shareer) Gunas $^{26}$, water has Drava, Snigdha, Sheeta, Manda, Mrudu, and Pichchhil Gunas ${ }^{27}$ by which, water does its functions. If taken in excess quantity, ultimately these Gunas are also abnormally increased unnecessarily in the body. This gives rise to increase in Kapha. ${ }^{28}$ This leads to increase in Meda and Mutra also; which is the main Dooshya in Prameha. ${ }^{29}$

Atyambupana is a Srotodushtihetu for Udakvaha \& Mutravaha Srotas. ${ }^{30}$ Ayurveda believes that Udeerana and Dharana of Adharaneeya Vega are two important aetiological factors of all diseases. ${ }^{31}$ Trushna (thirst) is included in Adharaneeya Vega. ${ }^{32}$ Udeerana of Trushna Vega means drinking of water in excess quantity even though not feeling thirsty. Dhaaran of Trushna Vega means not drinking the water even after feeling thirsty. So one should drink water when felt thirsty only according to the requirement. Intake of water is highly variable among different people and even within the same person on different days depending on climate, habits and level of physical activity ${ }^{33}$ and also on season ${ }^{34}$ and Prakruti $i^{35}$. If Ushna Guna is increased in the body, it causes loss of water from body through metabolic processes \& excess perspiration. Hence, Pitta Prakruti people with congenital predominance of Ushna Guna; have more desire for water intake. In Greeshma and Sharad Rutu also, there is predominance of Ushna Guna in the environment; leading to excess desire for water intake to compensate the loss of water from body. Hence, it has been advised to have optimum water intake according to the requirement. ${ }^{36}$ If anyone violates these rules about water intake frequently for a longer duration of time, it may lead to metabolic disorders like Prameha (diabetes) as stated above.

\section{CONCLUSION}

Prevention is always better than cure. There is no proved complete cure available for diabetes in today's era. Diabetes is getting converted into a lifestyle disorder rather than a disease. This metabolic disorder has more threatening complications as well. Diabetic nephropathy, neuropathy, retinopathy etc. are very common. Ayurveda has also emphasized Nidana Parivarjan (avoiding the consumption aetiological factors of any disease in all the ways) as the first line of treatment. Here, only one etiological factor has been discussed; which plays an important role in the pathogenesis of Prameha (diabetes). Hence it is beneficial to avoid excess water intake and follow the regimen advised in Ayurveda regarding water intake. Though, no previous work done has been found regarding Atyambupana as a Pramehahetu, survey studies can be done to know about its practicality in different geographical areas. This work would be a contribution to both Ayurvedic and health professionals from other streams of medical practices in managing Prameha (diabetes) in a better way to avoid its complications.

\section{REFERENCES}

1. Acharya Shukla V edited Charak Samhita, Published by Chaukhamba Sanskrit Prakashan, Reprinted in 2007 Nidansthan $4 / 5$

2. www.who.int - World health statistics 2012

3. Acharya Shukla V edited Charak Samhita, Published by Chaukhamba Sanskrit Prakashan, Reprinted in 2007 Sutrasthan 30/26

4. Acharya Shukla V edited Charak Samhita, Published by Chaukhamba Sanskrit Prakashan, Reprinted in 2007 Chikitsasthan 22/16
5. Harrison's Principles of Internal Medicine 18th edition, Volume 1, Chapter 45, page 341.

6. Dr Shastri A D, edited Shushrut Samhita, Published by Chaukhamba Sanskrit Sansthan, Reprinted in 2011 Uttartantra 49/3

7. Acharya Shukla V edited Charak Samhita, Published by Chaukhamba Sanskrit Prakashan, Reprinted in 2007 Chikitsasthan 26/104

8. Acharya Shukla V edited Charak Samhita, Published by Chaukhamba Sanskrit Prakashan, Reprinted in 2007 Chikitsasthan 13/45

9. Dr Shastri A D, edited Shushrut Samhita, Published by Chaukhamba Sanskrit Sansthan, Reprinted in 2011 Nidansthan 6/3

10. Kaviraj Atridev Gupt edited Ashtang Sangrah, Published by Krushnadas Academy, Varanasi, Reprinted in 2002 Sutrasthan 6/4

11. Kaviraj Atridev Gupt edited Ashtang Sangrah, Published by Krushnadas Academy, Varanasi, Reprinted in 2002 Sutrasthan 6/34

12. Vaidya L C. edited Ashtang Hrudaya. Motilal Banarasidas, Reprinted in 2005. Nidansthan 8/15

13. Vaidya L C. edited Ashtang Hrudaya. Motilal Banarasidas, Reprinted in 2005. Nidansthan 8/1

14. Acharya Shukla V edited Charak Samhita, Published by Chaukhamba Sanskrit Prakashan, Reprinted in 2007 Chikitsasthan 30/163

15. Acharya Shukla V edited Charak Samhita, Published by Chaukhamba Sanskrit Prakashan, Reprinted in 2007 Chikitsasthan 17/11

16. Vaidya L C. edited Ashtang Hrudaya. Motilal Banarasidas, Reprinted in 2005. Uttartantra 23/2

17. Vaidya L C. edited Ashtang Hrudaya. Motilal Banarasidas, Reprinted in 2005. Sutrasthan 11/34

18. Vaidya L C. edited Ashtang Hrudaya. Motilal Banarasidas, Reprinted in 2005. Sutrasthan 11/34.

19. Vaidya L C. edited Ashtang Hrudaya. Motilal Banarasidas, Reprinted in 2005. Sutrasthan 11/5.

20. Vaidya L C. edited Ashtang Hrudaya. Motilal Banarasidas, Reprinted in 2005. Nidansthan 10/7.

21. Dr Shastri A D, edited Shushrut Samhita, Published by Chaukhamba Sanskrit Sansthan, Reprinted in 2011 Nidansthan $1 / 19$

22. Acharya Shukla V edited Charak Samhita, Published by Chaukhamba Sanskrit Prakashan, Reprinted in 2007 Chikitsasthan 15/36

23. Acharya Shukla V edited Charak Samhita, Published by Chaukhamba Sanskrit Prakashan, Reprinted in 2007 Chikitsasthan 15/37

24. Dr Shastri A D, edited Shushrut Samhita, Published by Chaukhamba Sanskrit Sansthan, Reprinted in 2011 Nidansthan $1 / 20$

25. Acharya Shukla V edited Charak Samhita, Published by Chaukhamba Sanskrit Prakashan, Reprinted in 2007 Sutrasthan 26/10

26. Vaidya L C. edited Ashtang Hrudaya. Motilal Banarasidas, Reprinted in 2005. Sutrasthan $1 / 18$

27. Acharya Shukla V edited Charak Samhita, Published by Chaukhamba Sanskrit Prakashan, Reprinted in 2007 Sutrasthan 26/11

28. Acharya Shukla V edited Charak Samhita, Published by Chaukhamba Sanskrit Prakashan, Reprinted in 2007 Nidansthan $4 / 6$

29. Acharya Shukla V edited Charak Samhita, Published by Chaukhamba Sanskrit Prakashan, Reprinted in 2007 Niidansthan $4 / 5$ 
30. Acharya Shukla V edited Charak Samhita, Published by Chaukhamba Sanskrit Prakashan, Reprinted in 2007 Vimansthan 5/11 and 20

31. Vaidya L C. edited Ashtang Hrudaya. Motilal Banarasidas, Reprinted in 2005. Sutrasthan $4 / 22$.

32. Vaidya L C. edited Ashtang Hrudaya. Motilal Banarasidas, Reprinted in 2005 Sutrasthan 4/1

33. Textbook of Medical physiology by Guyton \& Hall 11th edition, chapter 25 , page 291

34. Vaidya L C. edited Ashtang Hrudaya. Motilal Banarasidas, Reprinted in 2005. Sutrasthan 5/14.
35. Acharya Shukla V edited Charak Samhita, Published by Chaukhamba Sanskrit Prakashan, Reprinted in 2007 Vimansthan 8/97

36. Vaidya L C. edited Ashtang Hrudaya. Motilal Banarasidas, Reprinted in 2005. Sutrasthan 5/14

\section{Cite this article as:}

Nilesh Dilipkumar Sharma. Study of atyambupana as a pramehahetu. Int. J. Res. Ayurveda Pharm. May - Jun 2016;7(3):16-18 http://dx.doi.org/10.7897/2277-4343.073103

Source of support: Nil, Conflict of interest: None Declared

Disclaimer: IJRAP is solely owned by Moksha Publishing House - A non-profit publishing house, dedicated to publish quality research, while every effort has been taken to verify the accuracy of the content published in our Journal. IJRAP cannot accept any responsibility or liability for the site content and articles published. The views expressed in articles by our contributing authors are not necessarily those of IJRAP editor or editorial board members. 